\title{
圧密理論の検討及び定圧圧密における 歪み硬化・回復過程の導入
}

\author{
Development of Consolidation Theory and Introduction of \\ Stress Hardening- Recovery Hypothesis for Constant Load Consolidation
}

\author{
長瀬 洋 一 * , 岡田賢治*, 銭紹 祥 ${ }^{*}$, 竹山宏 秋** \\ Youichi NAGASE, Kenji OKADA, Shaoxiang QIAN, Hiroaki TAKEYAMA
}

\begin{abstract}
We noticed that the boundary condition on the top surface of the consolidated bed in the theoretical calculations was incorrectly imposed in ref." and ref." ${ }^{2)}$ Revised calculations are presented in this paper. In ref." a new theory for the constant load consolidation was proposed together with a convenient boundary conditions on the bottom of the consolidated bed (Eq. (7) in this paper) which assumed that the void ratio suddenly jumped to the final value immediately after the loading. If strict forward consideration is assumed, the boundry condition (BC) should be varied with time according to the increases in friction and particle network stress, i. e., Eq. (8) has to be imposed in place of Eq. (7). However, the previous calculations together with Eq. (7) predicted the observed consolidation curves even until middle of the consolidation period. To overcome this contradiction is the main objective of this work. Variable load consolidation experiments are compared with theoretical calculations for both BC's. Calculations for frictionless wall on the constant load are also conducted and discussed. It is concluded from these examinations that during the constant load consolidation the stress hardening must occur after the loading to balance out the extra load until strain in the bed reaches to a normal stressstrain relation, since strain could develop only when dewatering from the bed has progressed. Modified theory including the stress hardening and recovery process predicts consolidation experiments quite well for the whole period of the consolidation. Master curves for the constant load and the variable load consolidations are also presented.
\end{abstract}

Key Words : Consolidation, Constant Load, Variable Load, Stress Hardening, Stress Recovery

\section{1. 緒言}

本文に先立って，論文 ${ }^{1,2)}$ の理論計算における境界 条件の設定に誤りが, 伴って, 計算䛊りがあったこと を陳謝する*11*2)。本報において訂正した計算結果を 新たな計算と合わせて Fig. 1，4 に示す。

著者らは側面拘束せず，排水もない高濃度スラッシ の1軸圧縮実験を行い，破壊以前の僅かな歪み範囲で 粘弾性を示す，この意味でスラッジは粘弾塑性体であ

1998年4月 6 日受付

拾体工学会春期研究発表会（1997年5月，京都）にて一部発表

* 倉数芸術科学大学

（テ712-8505 倉教市連島町西之浦2640）TEL 086-440-1164

Kurashiki University of science and the Art

(2640 Nishino-ura, Turajimacho, Kurashiki-shi, Okayama 712-8505)

**粕クボタ新淀川環境プラントセンター

（テ555-0042 大阪市西淀川区西島 2-1-6）TEL 06-475-3921 Shinyodogawa Enviromental Plant Center, KUBOTA Co. (2-1-6 Nishijima, Nishiyodogawa-ku, Osaka 555-0042)
ることを確認した ${ }^{3)}$ 。シリンダー内でスラッジを圧縮 するときは側面拘束され，かつ排水が起こる王密にな るので, 従来は圧密中の粒子ネットワークの力学特性 を推察できなかった" 。著者らは十分圧密し平衡に達 した層について, 載荷している荷重を急減させること によって，膨張回復歪みを測定することを考案した。 回復歪みと先に求めた粘弾性の弾性要素との積とし て, 圧密層の弾性応力を求め, その間隙比依存性を得 た。その際に壁摩擦が無視できないことを同時に見い

\footnotetext{
*11 压密層上面における境界条件として液圧勾配を零とおいていた。 正しくは本報Eq. (6) でなければならない。この誤謬のために計算 压密曲線は㬰験と一致しなくなるか，時定数 $\lambda_{c}$ の定義に関せず便 宜に与え，また压密の実測値を部分修正していた。なお，論文 ${ }^{2)}$ は理論計算が正当であるとして、液圧分布等を提示しているか，現 時点では理論の正確度を実験的に立証するのが困難であるので（本 報参照)、これらの訂正は差し控える。論文 ${ }^{2 \prime}$ のFig. 1（a）を削除 する。

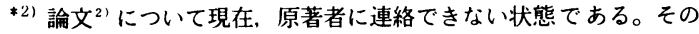
ため論文 ${ }^{1 !}$ の共著者であり、また論文 ${ }^{21}$ の実験を提起した責任上. 原著者に代わって両編をまとめて訂正せざるを得ない。
} 
だした。また透水抵抗は Kozeny-Carman 式に従う ことを確認し、これらをまとめて壁摩摖を考慮した新 しい压密方程式を誘導した。これを検証するために 定压压密について従来と同様な境界条件を商用したと ころ，压密の中期まで計算圧密曲線が実験と一致し た ”。しかし適用した境界条件は論理の一貫性に欠け るので，中期までにせよ実験と一致した理由を探るた めに，荷重を徐々に增大させる変圧圧密実験 ${ }^{2)}$ を追加 し，考察を加えることにした。その結果，圧密のメ力 ニズムについて新たな知見がえられ，また前報の境界 条件が論理性に欠ける理由も明らかになったと考える ので報告する。また実用に便利な無次元圧密曲線を提 示する。

\section{2. 境界条件及び圧密曲線の多様性}

\section{1 境界条件}

後に必要になるので, 前報で誘導した主要な関係式 及び境界条件を列記する。压密においては排水が起こ ることによって始めて，層内歪みや間隙比の変化が同 時に起こる。しかるに排水は時間遅れを伴うので, 歪 み（間隙比と関連する物理量ではない）はゆっくり増 加することになる。そこで一軸圧縮実験結果が拡張適 用できるとすると，粒子層は破壊することなく，かつ 粘弾性のうちの弾性のみが表れるはずである。以下で $\sigma$ はかような意味の弾性応力である。

弾性応力の間隙比依存 :

$$
\hat{\sigma}=\frac{\sigma}{\alpha}=\exp (-\beta e)
$$

力の釣り合い式 : 任意時間, 任意面（ $w$ で表す）にお いて, 荷重 $F$ は粒子ネットワーク強度 $\alpha$, 間隙水压 $p$ 及び層上面より $w$ までの壁摩擦（Eq. (2) 右辺第 3 項）之平衡する。摩擦係数相当値 $\tan \phi$ は一定と近似 する"。

$$
\hat{F}=\hat{\sigma}+\hat{p}+\int_{\dot{w}}^{1.0}(1+e) \frac{2}{R} \hat{\tau}_{w} \mathrm{~d} w, \quad \hat{\tau}_{w}=\hat{\sigma} \tan \phi
$$

脱水速度式 : Eq. (2) をwで偏微分し， $\partial F / \partial w=0$ を 考慮して， $\partial F / \partial w に K o z e n y-C a r m a n$ 式を代入。

$$
u=\frac{e^{3}}{(1+e)^{2}}\left\{A(1+e) \hat{\sigma}-\frac{\partial \hat{\sigma}}{\partial \hat{w}}\right\}, \quad A=\frac{2 w_{0} \operatorname{ten} \phi}{R}
$$

連続式：

$$
\frac{\partial e}{\partial \hat{t}}=\frac{\partial \hat{u}}{\partial \hat{w}}
$$

以上はEq. (1) の係数 $\alpha$, 及び固体のみの全高さ $w_{0}$ を用いて，次のように無次元化している。

$$
\hat{\sigma}=\frac{\sigma}{\alpha}, \hat{w}=\frac{w}{w_{0}}, \hat{t}=\frac{t}{\lambda_{c}}, \lambda_{c}=\frac{\mu k w_{0}^{2}}{\alpha}, \hat{u}=\frac{u \lambda_{c}}{w_{0}}
$$

Eqs. (1) 〜 (4) を連立して解く場合の初期条件は 前報"で述へた。用いた圧密実験装置は両面排水方 式であるので，(前報 ${ }^{31} ，$ Fig. 7 参照)，層の上表面

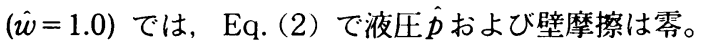
よって荷重はすへて粒子ネットワークに伝えられ，層 上面の境界条件は次式になる。

$$
\text { BC 1. } \begin{aligned}
(\hat{w}=1.0): \hat{F}_{i} & =\hat{\sigma}_{i}(1) \quad \text { 予備压密, } \\
\hat{F}_{\mathrm{f}} & =\hat{\sigma}(1) \quad \text { 本厈密。 }
\end{aligned}
$$

層底面でも液圧は零であるが，Eq. (2) にしたがっ て壁摩擦が発達しているので, 荷重 $\hat{F}_{\mathrm{f}}$ は層底に達し ない。前報"では，層底における境界条件として，従 来の圧密理論が層底では圧密開始直後に平衡値に達す るとしていることを考慮して，層底における間隙比 $e(0)$ は压密後, 直ちに圧密平衡におけるそれ（時間 に関係なく一定）になる。すなわち層底面の境界条件 として，次式を設定した。

BC 2. $(\hat{w}=0)(そ の 1)$ :

$$
\begin{aligned}
& \boldsymbol{e}_{f}(0)=\left(1+e_{f}(1)\right) \exp (A / \beta)-1, \\
& A=\frac{2 w_{0} \tan \phi}{R}, \quad e_{f}(1)=\ln F_{f} /(-\beta)
\end{aligned}
$$

しかし層底のみが理論に関せず最終平衡値に達し, その直ぐ上方では, Eqs. (1)〜（4）に従って壁摩擦 を含めて, 全体にわたり圧密が進行してゆくとするの は理論の一貫性に欠ける。

本理論が妥当であるとすると, 時間 $t=t$ における底 面上の応力は Eq. (2) より, 対応して間隙比は Eq.

(8) 第 2 式で与えられるはずである。

$\mathrm{BC} 2 .(\hat{w}=0)($ その 2$):$

$$
\begin{aligned}
& \hat{\sigma}(0, \hat{t})=\hat{F}_{f}-\int_{0}^{1.0} A(1+e(\hat{w}, \hat{t})) \hat{\sigma}(\hat{w}, \hat{t}) \mathrm{d} \hat{w} \\
& e(0, \hat{t})=\ln \hat{\sigma}(0, \hat{t}) /(-\beta)
\end{aligned}
$$

この条件によると, 本圧密開始時点では予備圧密終 了時の小さい荷重 $F_{i}$ に対応する壁摩擦が残っている 

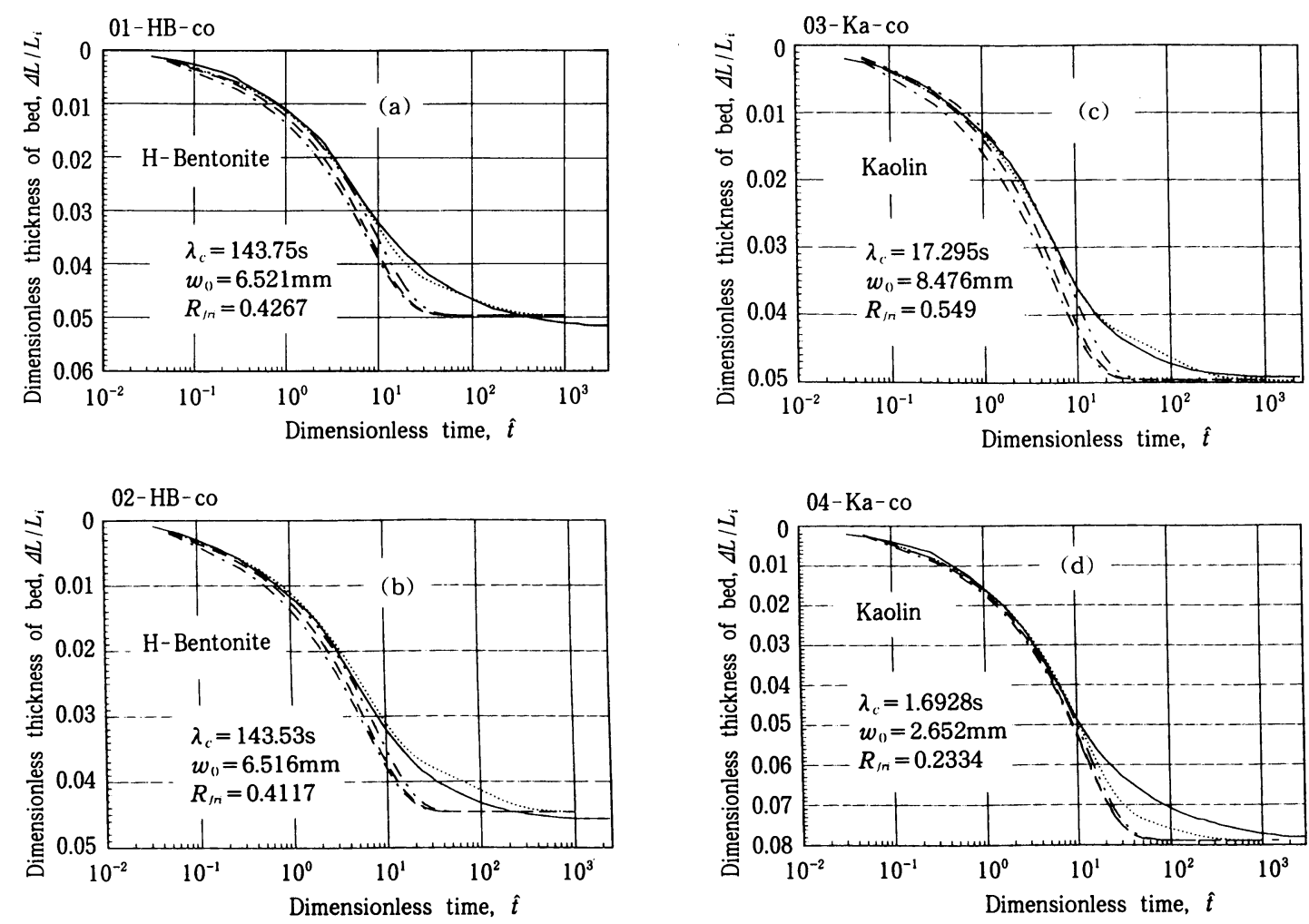

Fig. 1 Constant load consolidation curves observed and calculated on boundery Conditions, Eqs. (7) $\cdot(9)$ and (13) : ——, observed ; - -..-..- Eq. (7) ;

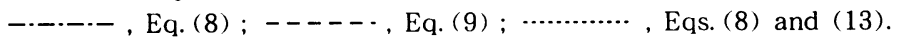

ので，本圧密開始直後に層全体が大きく圧縮される。 とくに層底付近では一旦強力に脱水され（過圧密と仮 称する), その後過圧密が解消されるに伴って再度吸 水が起こり, 平衡值に近つくことになる。結果として 圧密はEq.（7）の条件の場合よりも急速に進展するこ とになり，実験王密曲線に合わない。理論は不完全で あることになる。再考するために，荷重を徐々に増 加する変圧圧密実験を追加することにした（緒言参 照)。

対比するために，本理論を壁摩擦がない場合にも拡 張する。この場合はEqs. (2), (3) で $\tan \phi=0$ 。両面 排水のときは層中央断面に関して上下対称になるか ら，首底の境界条件BC 2 は BC 1 に一致する。

BC 2. $(\hat{w}=0)($ その 3 。壁摩擦なし):

$$
\hat{\sigma}(0)=\hat{\sigma}(1)=\hat{F}_{f}, e(0)=e(1)
$$

この条件は層中央において, 液圧勾配 $(=\partial p / \partial w)$ を 0 とおくことと同等である*11。

\section{2 圧密研究の難点}

前報"（Table 1）に示した諸係数值を用い，底面 の境界条件を Eqs. (7) 〜 (9) としたときの定圧圧密 曲線の計算結果と実験結果の対比を Fig. 1 (a) 〜 (d) に示す（前報" Fig. 3（a）～(d) に対応)。各図に Eq. (5) で定義した $\lambda_{c} ， w_{0}$ 及び圧密最終における壁 摩擦の総和と荷重との比,

$$
R_{f r i}=\frac{\int_{0}^{1.0} A\left(1+e\left(\hat{w}, \hat{t}_{f}\right)\right) \hat{\sigma}\left(\hat{w}, \hat{t}_{f}\right) \mathrm{d} \hat{w}}{\hat{F}_{f}}
$$

をFig. 1に付記した。 $w_{0}$ 以外の実験条件は前報" 示されている。境界条件 Eq. (7) による王密曲線（二 点鎖線）が圧密中期まで（縦軸について）実験結果と ほぼ一致することを再確認した。Eq.（8）の場合は （一点鎖線）上記した理由で，王密が急速に進行して いる。点線で示す曲線は次項で述べる。

注目されることは実験条件によって $R_{f r}$ が $55 \%$ 


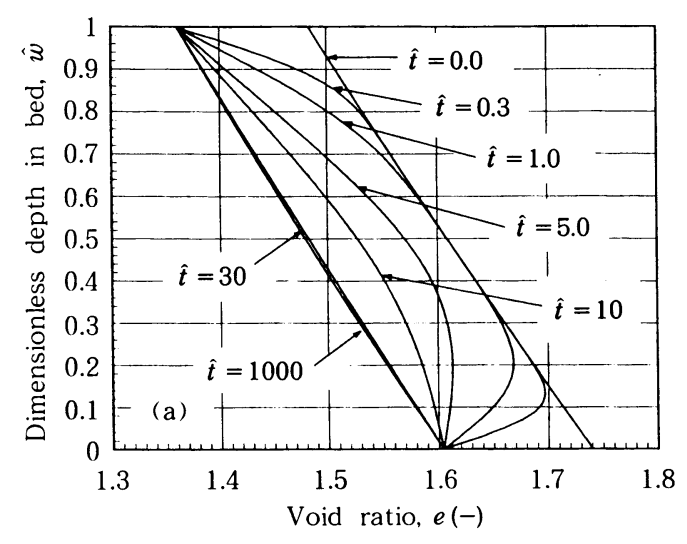

03-Ka-co, frictionless

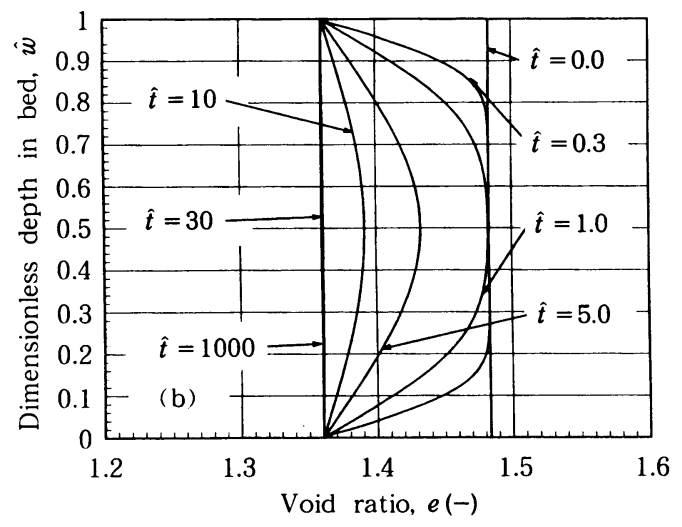

Fig. 2 Develpoment of $\boldsymbol{e}$-distributions with time-an illustration (experimental conditions refer to Fig. 1 (c)) : (a) calculated on boundary condition, Eq. (7) ; (b) calculated on boundary condition, Eq. (9).

$23 \%$ と変化しているにもかかわらず, 実測圧密曲線 は壁摩擦なしの場合（破線）のそれとわずかにずれて いるだけである。压密曲線は壁摩擦に対して鈍感であ ることが分かる。圧密曲線が積分量であるためで，間 隙比や応力の局所分布でないと顕著な相違は表れな い。その例を Figs. 2,3に示す。壁摩擦なしの場合は,

予備圧密終了時に $e$ または $\hat{\sigma}$ は一定, 圧密開始ととも に上下対称に変化し, 再び一定值に収束する。壁摩擦 があるときはこれらの曲線の上面のみが摩擦なしと一 致し, 以下全体に右下方向 ( $e$ 分布) 又は左下方向に ずれた分布 $(\sigma)$ となる。層平均間隙比は壁摩擦なし の方が元々小さいなど，その相違は顥著である。理論 （次項の計算を含めて）の完成度，壁摩擦の推定精度 等は層内の応力，または間隙比の局所分布測定結果と 対比しないと判定できない。しかしそのために層厚さ

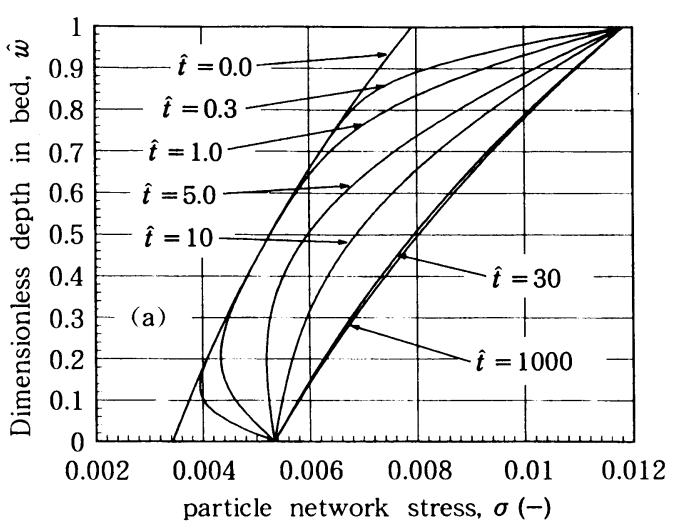

03-Ka-co, frictionless

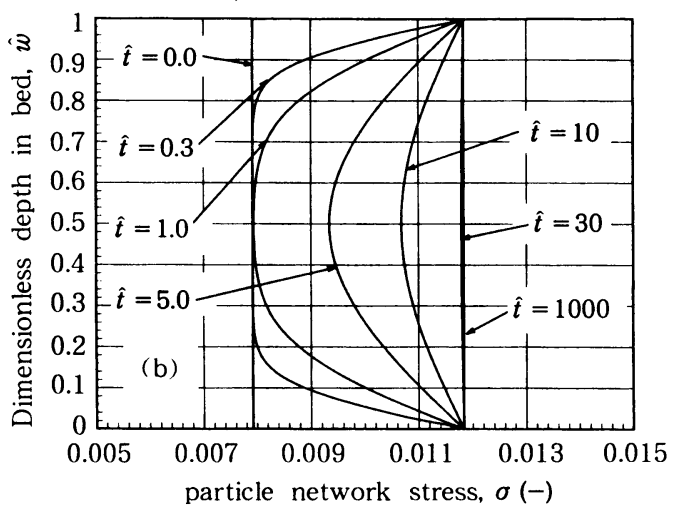

Fig. 3 Develpoment of $\sigma$-distributions with time-an illustration (experimental conditions refer to Fig. 1 (c)) :

(a) calculated on boundary condition, Eq. (7) ; (b) calculated on boundary condition, Eq. (9).

を大きくすると，再現性のあるデータを得ることが極 めて困難になる。層厚さを小にすると, 数ないし十数 $\mu \mathrm{m}$ 厚さに層をスライスし, かつスライスした層の $e$ を正確に求めなければならず*3)，大がかりな設備を 要する。著者が知る限りでは, 土質力学の分野でも局 所の $e$ または $\hat{\sigma}$ の測定は行われていない*4)。従って 著者らが展開してきた理論の厳密度を検証できていな い。しかし本理論で, Eqs. (2), (4) は法則であり, Kozeny-Carman 式は広く認められているので, 弾 性体と仮定して実験的にえられたEq. (1), 及び壁摩

\footnotetext{
*3) 理論の完成度は, 压密開始直後の層底面，表面付近における $e$ の急激な変化（本理論では著しく非線形な変化）に端的に表れる。 压密終了付近において理論式は線形化する。

*4) 今井の実験があるが，王密層を 7 層に分割しているに過ぎす， かつ各分割層には液圧しか伝達されない装置構造なので゙、本理論 の直接検証には適しない。
} 
擦の推定値 $\tan \phi$ が問題になるのみである。ところで Fig. 1 (a) 〜 (d) のすべてについて圧密が平衡に達す る実測時間, Eq. (7) による計算が実測曲線からずれ 始める時間は, $\hat{t}$ として, それぞれの 1500 2000及 び約 5〜8であるなど, 実験誤差を考慮すると, 特性 時間は共通していると認められる。このことは压密時 定数 $\lambda_{c}$ の定義が妥当であることを例示している。ま た压密平衡に達したときの縦軸値は計算とほぼ一致し ている (4. 2 項で再述する)。これらの結果はEq. (1) が大約妥当であることを示しているものと考えられ る。そうとして以下の考察を続ける。

\section{3. 変圧圧密の解析}

本理論は粒子層の強度, 層の透水抵抗を考慮して いるので, 変圧厌密の場合も, 上記諸式で $\hat{F}_{f}$ を実験 条件に従って変化させるだけで計算可能である ${ }^{21}$ 。変 压圧密の内でも最も単純な実験を行ったに過ぎない が、この実験に対する条件式（7）および（8）によ る計算結果を, Fig. 4 (a)〜（c）に示した（論文 ${ }^{2)}$, Fig. 1 (b) 〜 (d) に対応)。荷重変化パターンおよび $\lambda_{c}, w_{0}, R_{f r i}$ を図中に付記している。荷重変化パタ一 ンと圧密曲線を対比すれば明らかなように, 実験は荷 重が一定になるまでの載荷速度を意識的に小さくして いるので, 荷重増加域の終点において, 圧密はほぼ終 わっている。このような場合は, 条件式 (7),（8）に よる計算結果は全時間にわたってほぼ完全に一致して いる。また压密の最終期を除いて, 計算結果は実験と よく一致している。なお変圧が定压よりも効果的な压 密方法であることは ${ }^{2}$, Fig.1 とFig. 4 の $R_{f r i}$ を対比 すれば容易に知ることができる。外力を徐々に增加さ せることによって, 壁摩擦の発達が遅れ, それだけ外 力が压密に有効に利用されるためである。

\section{4. 定圧圧密における歪み硬化・回復の仮定}

\section{1 仮 定}

条件式（8）は定圧圧密では実験結果から全くずれ ているのに対して, Fig. 4のように荷重変化が僅かで ある変圧圧密においては, ごく限られた終期でのみず れるに過ぎないことを確認した。このことと, 条件式 （7）が本理論からすると一貫性に欠けることとを，ま とめて矛盾なく説明できる唯一の概念は次のようであ ろう。

定圧圧密では, 予備圧密荷重 $\hat{F}_{i}$ から本圧密荷重 $\hat{F}_{f}$ に荷重が急激に変化する。しかし, 粘性遅延のため に, 脱水が対応して急激に起こることは出来ない。脱
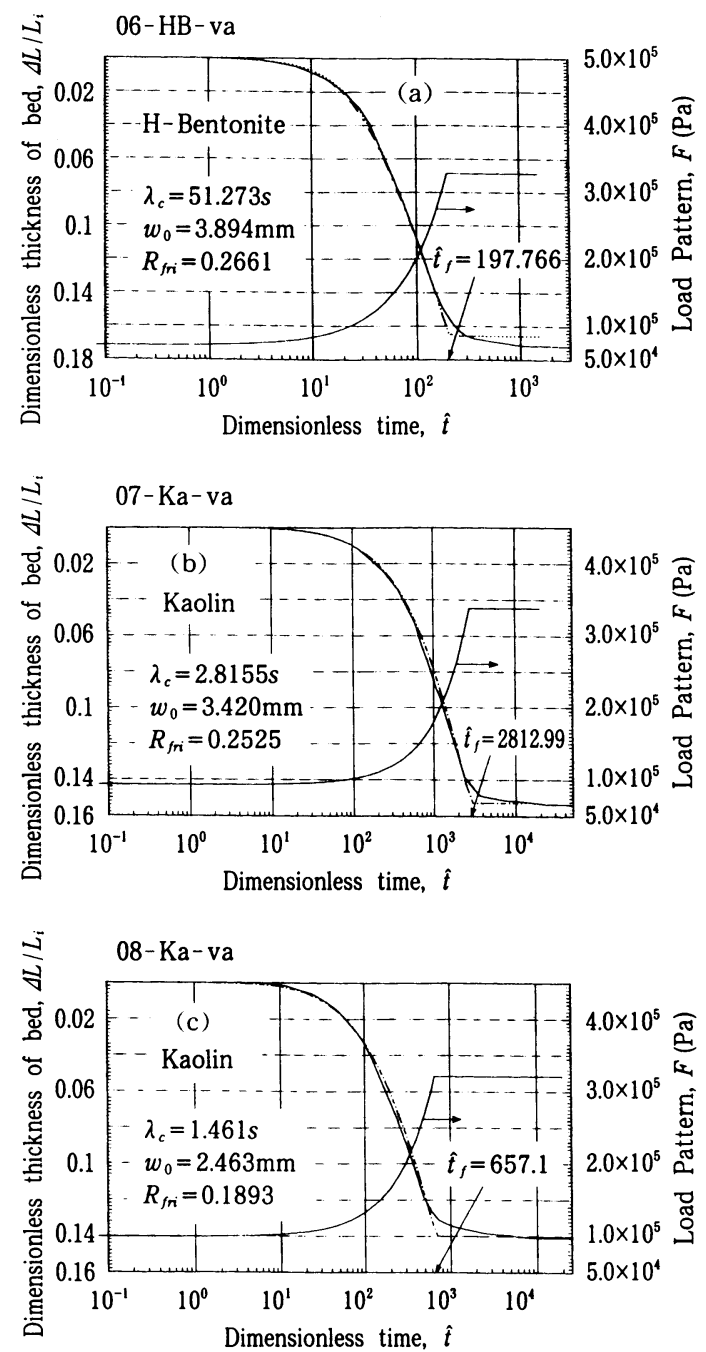

Fig. 4 Variable load consolidation curves and calculated on boundary conditions, Eqs. (7) and (8):- observed ; --- , Eq. (7) ; -...-, Eq. (8).

水しなければ歪み増加は起こりえず, 応力変化も起こ らない。結局荷重の急変に対応するには, 粒子ネット ワークが歪みを硬化を起こして過剩外力と平衡する他 ない。著者らは, 以前より一軸圧縮実験によって, 粒 子層は外力が急增したときに歪み硬化を起こす, 除荷 して長時間放置すると, 元の粘弾性に回復する（逆于 キソトロピー）性質があることを強調してきた5, 6)。 側面が非拘束である場合でもそうであるから, 側面拘 束されている定圧圧密においては, なお歪み硬化を起 こし易いであろう。

そこで, 外力が急変するときに歪み硬化を起こす, 


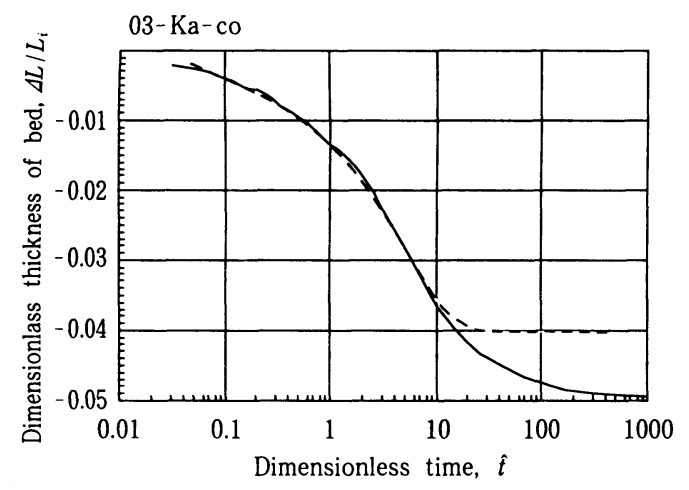

Fig. 5 Constant load consolidation curve calculated under hardening assumption given by Eqs. (11) and (12) (experimental conditions refer to Fig. 1 (c)) : solid line, observed; dotted line, caiculated.

そうでない変圧圧密では硬化が起こらない, 定圧圧密 でも脱水が進行して，歪みが大きくなってくると，以 後はチキソトロピー的に元の応力・歪み関係に回復す る，と仮定することにする。従って以下は定圧圧密の みを対象にする。

\section{2 近似表示}

上記の意味の歪み硬化・回復過程を単純に表現する ために, Eq. (1) を次式のように修正する。

$$
\hat{\sigma}=\varphi(\hat{t}) \exp (-\beta e)
$$

修正項 $\varphi(\hat{t})$ は無次元時間のみの関数とする。上式で まず硬化のみを検討するために,

$$
\varphi(\hat{t}) \equiv 1.082
$$

とおいて簡略化し，境界条件式 (8) を適用して, Fig. 1 (c) の実測圧密曲線之対比した例を Fig. 5 に示す。 Eq. (12) はEq. (1) の係数 $\alpha$ を大にしたのと同様であ るから, 圧密最終の縦軸値は実際よりも大きくなる。

極めて注目されることは, Fig. 5 と同様にFig. 1 (a)，(b)，(c)，(d) の何れについても，計算曲線は $\hat{t}=5-8$ 程度まで実測曲線にほぼ一致し，はずれ始め る横軸値は境界条件式（7）による計算がはずれる横 軸値, 及び既往の Terzaghi 式による計算結果が実測 とはずれ始める横軸値などとほぼ一致していることで あった（再計算して確かめた）。このことは仮定及び 理論が妥当であるとすると, 不自然であった条件式 （7）は，圧密曲線に関して歪み硬化と同等な効果をも たらしていたこと（压密曲線は境界条件に鈍感であ る)，また Terzaghi 式或いはその修正式を基本とす
る土質力学分野の研究において, 二次圧密域といわ れてきた圧密後期は, 本理論では歪み硬化から元の 応力・歪み関係に回復してゆく，すなわち粒子ネッ トワークのメカニズムが変化する領域であると説明 される。仮定は压密曲線についてしか確認できない 段階であるが, 論理体系としては一貫していると考え る。 $\hat{t}=5-8$ 程度までEq. (12) のように硬化を表す係 数が一定であったのは, 本実験に関する限りは Eq. （12）が硬化の上限に対応していること，この時間程 度まで脱水して始めて, 層内がいわば正常な応力・歪 み関係に回復し始めることを意味しているのであろ う。

Eq. (12) を考慮して, 硬化・回復の全域を総括す る簡単な関数が存在すれば便利であるので, 次式のよ うな近似を行ってみた。

$$
\varphi(\hat{t})=1.0+0.085 \exp \left\{-\left(\frac{\hat{t}}{80}\right)^{0.8}\right\}
$$

計算結果は, Fig. 1（a）〜（d）の点線で示してい る。Fig. 1 (b)，（d）については圧密後期において実 験曲線之計算曲線との一致は余り良くない。このず れ，またFigs. 1，4の各図において，压密最終の綐軸 実験値が計算のそれとほぼ一致したり，ずれていたり しているのは, 圧密終期の首厚さの測定が困難である ことによっていると考える。

なおFig. 4 (a)〜（c）においても，圧密曲線の終期 において計算は実測とずれているので，上記の推論に よると, 変圧圧密においても幾分は硬化・回復が起こ っていることになるが，ここでは扱わないことにす る。

Eq. (13) とEq. (8) を用いたときの, $e$ 及び $\hat{\sigma}$ 分布 の時間変化の一例を Fig. 6 (a), (b) にまとめて示し た。これらとFig. 2（a)，Fig. 3（a）とを対比する と, Fig. 6の方が遥かに複雑な変化を与えていること が分かる。すなわちFig. 6では歪み硬化を認めてもな お，境界条件 Eq. (8) に関連して述へた層底面付近に おける過圧密と再吸水が, 僅かであるが起こっている $(\hat{t}=0.3$ 及び1.0で, $e(0)$ と $\hat{\sigma}(0)$ はそれぞれ最終值よ りも，小，大である)。層上部では硬化を与えたこと で, $\hat{\sigma}$ 分布が $\hat{t}=0.3$ で, すでに初期分布から大きく ずれている。対応して $e(1)$ は最終値に一致しなくな っている。過王密からの解放は, $e$ 分布については $\hat{t}=5-30$ の間で起こり $(\hat{\sigma}$ 分布は $\hat{t} \fallingdotseq 30$ で最終分布と ほとんど一致しているが)，その後層全体にわたって ほぼ一様に再度圧密され，最終分布に漸近している。 


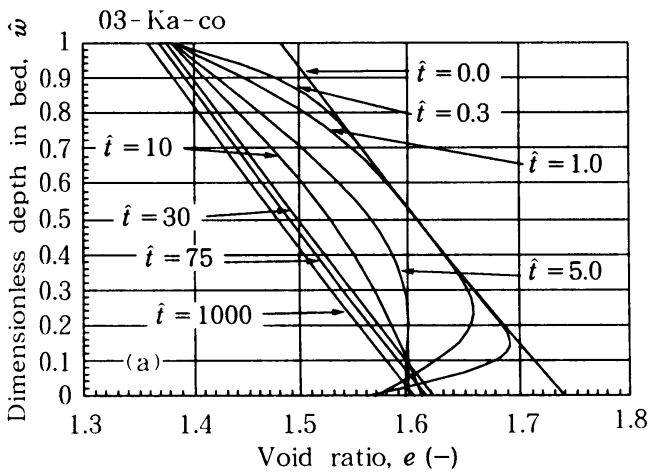

$03-\mathrm{Ka}-\mathrm{co}$

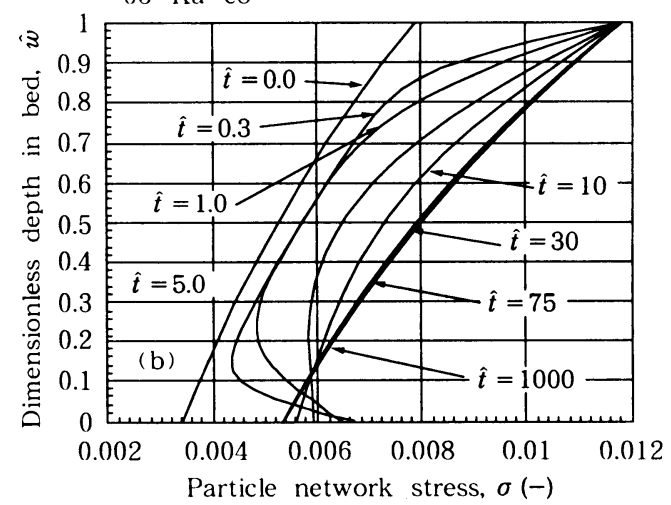

Fig. 6 Develpoments of $\boldsymbol{e}$ and $\sigma$-distributions with time under assumption of hardening and recovery given by Eq. (13) (experimental conditions refer to Fig. 1 (c)) :

(a) $e$-distributions ; (b) $\sigma$-distributions.

一方Fig. 2 (a) では， $\hat{t}=30$ ですでに最終分布とほ ぼ重なっている。このように大幅に相違するので, 仮 定の厳密な検証は局所分布の実測による他ない。

\section{5. 圧密の主パラメータ及び圧密曲線の近似マス ターカーブ}

本理論では, 压密の主パラメータはEq. (5) の時定 数 $\lambda_{c}$ である。各種の条件で行った定圧及び変圧圧密 実験によって，このことを確認した。実際に $\lambda_{c}$ は弾 性を代表する係数 $\alpha$ ，透水抵抗を代表する係数 $\mu k$, 層厚さを代表する $w_{0}$ の主要な 3 因子を含んでいる。 Eq. (2) で壁摩擦を無視できるときは, 外力は弾性要 素と粘性要素との和よりなるので, $\lambda_{c}$ の物理的意味は 層厚さの補正をした Voigt 的遅延弾性を表すといえ る。第 2 のパラメー夕は, 壁摩擦を代表する $\tan \phi 及$ びEq. (1)のßである。これら多数の係数を実験的に

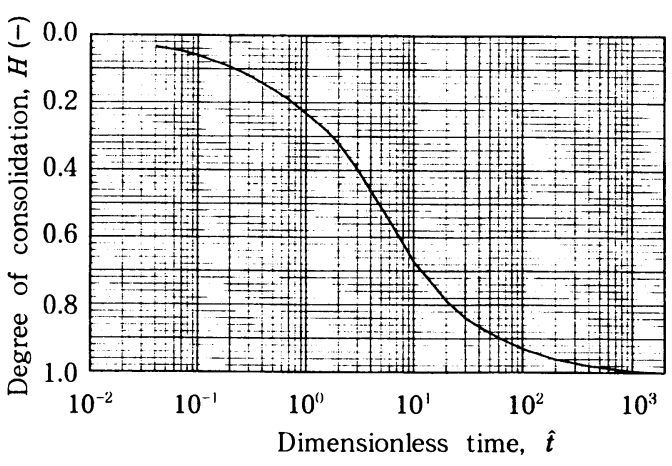

Fig. 7 Approximate master curve for constant load consolidation.

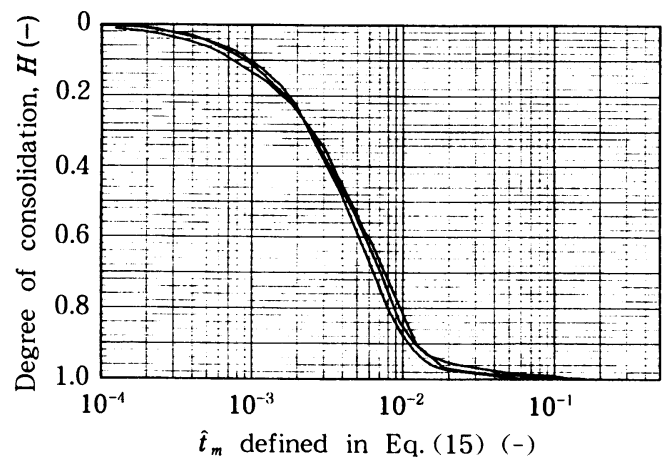

Fig. 8 Variable load consolidation curves to present approximate master curve

求めるのは面倒な手数を要するのであるが, 圧密曲線 に関する限りは壁摩擦の影響はわずかであった。また $\beta$ の相違は次式の圧密度に変換すると陽に現れない。

$$
H=\frac{L_{i}-L}{L_{i}-L_{f}}
$$

そこで压密度対無次元時間の実験結果を平均した圧 密曲線は近似のマスターカーブとみなすことができ る。こ机に圧密実験データをフィッティングさせる と, 主パラメー $\lambda_{c}$ を容易に推定でき, 压密の概要を 知ることができる。

定圧厌密 : 4 本のグラフを平均化して得た定圧圧密 の近似マスターカーブを Fig. 7に示す。

Fig. 4のような荷重パターンの変圧压密の場合 : こ の場合は荷重増加中に圧密度が $90 \%$ 以上に達するの で, 压密曲線の横軸は主として荷重増加率によって左 右される。これを無次元化して横軸を次のように修正 する。 


$$
\hat{t}_{m}=\frac{F_{\mathrm{ff}}-F_{i}}{\alpha \hat{t}_{f}} \hat{t}=\frac{\Delta \hat{F}}{\hat{t}_{f}} \hat{t}
$$

$F_{\mathrm{ff}}$ は定荷重に達したときの荷重, その他の記号は Fig. 4 を参照。Fig. 4 のデー夕を $H$ 対 $\hat{t}_{m}$ 曲線に変換 した結果を Fig. 8 に示す。3 本の曲線はほとんど一致 しており, マスターカーブとして利用できる。

\section{6. 結 言}

理論の完成度を詳細に検証できないのであるが，時 定数の定義は妥当, 圧密最終值の予測も可能である。 また本理論によると, 層底面の境界条件は Eq. (8) で なけ机ばならないことを変圧压密について確かめた。 これらによって理論の骨格は合理的であることを示し
た。その結果, 定圧圧密では压密開始から中期まで歪 み硬化し, 以後元の応力・歪み関係に漸次回復すると の仮説を提起した。仮説は過去の実験から類推して合 理的であると考えられるが，なお今後の検討に待たれ る。ひるがえって, 仮定が妥当であるとすると, 歪み 硬化を起こすような定圧厌密は圧密目的からすると不 利な方法である（このことは技術的には衆知のこと で, 回避されている)。今日まで圧密に関与する主要 な因子を求める目的で, 定圧厌密実験が重視されてき たのであるが，定圧でない実験方法に変換する方がよ いと思われる。

最後に, 実用の便宜に供するために, 定圧及び変圧 圧密の近似マスターカーブを提示した。

\section{Nomenclature}

$\boldsymbol{e}:$ void ratio $=$ (liquid volume) $/($ solid volume) $(-$ )

$F$ : consolidation load

$(\mathrm{kPa})$

$H$ : degree of consolidation definied in Eq. (14) (-)

$k$ : coefficient in Kozeny-Carman Eq.

$L$ : thickness of consolidated bed at $t=t$

$\Delta L$ : thickness variation with time $\left(=L_{i}-L\right)$

$R$ : radius of consolidated bed

$\tan \phi:$ friction coefficient defined in Eq. (2)

$t$ : time

$u$ : superficial liquid velocity in bed

$w$ : volume of dry solid per unit area

$(\mathrm{m})$

(m)

$(\mathrm{m})$

$(-)$

(s)

$(\mathrm{m} / \mathrm{s})$

(m) $w_{0}$ : total volume of dry solid per unit area

$\alpha$ : coefficient defined in Eq. (5)

$\beta$ : coefficient defined in Eq. (1)

(m)

$(\mathrm{kPa})$

$\mu$ : liquid viscosity

$\lambda_{c}$ : time constant defined in Eq. (5) $\sigma$ : particle network stress

$\tau_{w}:$ wall friction

Subscript

i : represent of initial condition $(t=0)$

f : represent of final condition $\left(t=t_{f}\right)$

\section{References}

1) Wu, X., H. Itou, K. Ono and Y. Nagase : "Consolidation Analysis-An Approximate Theory of Consolidation-", J. Soc. Powder Technol. Japan, 33, 10-16 (1996)

2) $\mathrm{Wu}, \mathrm{X}$. : "A Study of Variable-pressure Consolidation”, J. Soc. Powder Technol. Japan, 34, 84-90 (1997)

3) Wu, X., A. Mukunoki and Y. Nagase : "Consolidation Analysis - Mechanical Characteristics of a Particle Bed -", J. Soc. Powder Technol. Japan, 33, 4-9 (1996)

4) Imai, G., S. Onodera, K. Tatsuuma and T. Moritoh : "A Study on Consolidation Mechanism in Clay
Layers by Use of Connected Oedometers", 22th Doshitsukougaku-Kennkyu-Hapyoukai, pp. 243-246 (1987)

5) Nakamaru, H., T. Yuzuki and Y. Nagase: "Rheology of Sludge-Rupture Behavior-", J. Soc. Rheology, Japan, 16, 66-71 (1988)

6) Nakamaru, H., Y. Tawara and Y. Nagase : "Rheological Behavior of Highly Filled Ceramic Suspensions", J. Soc. Powder Technol. Japan, 31, 241-247 (1994) 